\title{
Growth, physiological and biochemical responses of Meliaceae species - Azadirachta indica and Melia dubia to elevated $\mathrm{CO}_{2}$ concentrations
}

\author{
S. Janani, P. Priyadharshini, R. S. C. Jayaraj, C. Buvaneswaran, Rekha R. Warrier* \\ Institute of Forest Genetics and Tree Breeding, P.B.No.1061, R.S.Puram, Coimbatore-641002, India.
}

\section{ARTICLE INFO}

Article history:

Received on: 31/03/2016

Revised on: 13/05/2016

Accepted on: 29/05/2016

Available online: 21/06/2016

Key words:

$\mathrm{CO}_{2}$, Melia dubia, neem, gas

exchange, metabolites,

growth, native trees, Open

Top Chambers

\begin{abstract}
Response of two important tropical tree species of Meliaceae (Azadirachta indica - neem and Melia dubia melia) to elevated levels of $\mathrm{CO}_{2}(600$ and $900 \mathrm{ppm})$ under simulated temperature and moisture regimes in Automated Open Top Chambers was studied. Growth, biochemical changes, antioxidant property and gas exchange parameters were estimated. The results indicate that $A$. indica is expected to acclimatize under elevated $\mathrm{CO}_{2}$ concentrations whereas $M$. dubia was observed to be a species sensitive to elevated $\mathrm{CO}_{2}$ concentrations, affecting the photosynthetic machinery, stomatal conductance and transpiration and a subsequent decrease in carbohydrates, proteins, sugars, amino acids and phenolics. The short-term and long-term responses with respect to stomatal conductance and transpiration rates were higher in neem than melia. Thus, a positive response of neem to increased $\mathrm{CO}_{2}$ concentrations is a good indication for its future establishment in potentially changed climatic conditions.
\end{abstract}

\section{INTRODUCTION}

Plants acclimatise and adapt to the prevailing environmental conditions to optimize their growth and survival. It is well demonstrated that the growth and morphology related responses of plants to elevated atmospheric carbon dioxide concentration vary according to species and are dependent on the environmental conditions[1]. Different species respond differently to elevated carbon dioxide. Most plants growing in experimental environments with increased levels of atmospheric carbon dioxide exhibit increased rates of net photosynthesis and reduced stomatal conductance, resulting in increased productivity [2] and an enhancement in water-use efficiency [3]. Stimulation of carbon assimilation resulting from increased internal $\mathrm{CO}_{2}$ concentrations in enriched environment leads to increased stem and foliar biomass [4]; greater root biomass and volume [5]; and stimulation of root symbiotic associations [6,7]. The effect of elevated $\mathrm{CO}_{2}$ on net photosynthesis in temperate trees has been well documented [8,9]. Net photosynthesis in loblolly pine trees and seedlings has been demonstrated to be boosted by both short and long term exposure to elevated $\mathrm{CO}_{2}$.

* Corresponding Author

Tel: 91422 2484167; Fax: 914222430549

Mailid: rekhawarrier@gmail.com
The effect of elevated $\mathrm{CO}_{2}$ on tree biomass production has been well characterized. In general, under optimum growing conditions (i.e. adequate nutrients, water and light), long term exposure to elevated $\mathrm{CO}_{2}$ (approximately double ambient $\mathrm{CO}_{2}$ for one season or more) can increase biomass by up to $130 \%$ in conifer and $49 \%$ in deciduous trees [10]. On an average, biomass production was stimulated by approximately $31 \%$ in loblolly pine grown in elevated $\mathrm{CO}_{2}[11]$

The combined effect of elevated $\mathrm{CO}_{2}$ and elevated temperature may have an interactive effect on Anet. While fewer studies have investigated the effect of both elevated $\mathrm{CO}_{2}$ and temperature, there are reports of both positive and negative responses in different studies. In mature Picea abies ((L.) Karst.) [12] and in seedlings of loblolly pine there was an increase in the optimum temperature for Anet in trees grown under elevated $\mathrm{CO}_{2}$. Contrarily, mature Pinus sylvestris (L.) [13] and Betula papyrifera, Picea mariana and Populus tremuloides [14] observed a decrease in Anet with an increase in temperature under both ambient and elevated $\mathrm{CO}_{2}$ suggesting that there was no interactive effects of temperature by $\mathrm{CO}_{2}$ treatment interaction. The present study was taken up to investigate the biochemical responses of two tropical tree species of family Meliaceae to elevated $\mathrm{CO}_{2}$. 
The two species selected for the study are commercially important in the family Meliaceae - Azadirachta indica (neem) and Melia dubia (melia). The former, popular for its timber and medicinal principles is slow growing while the latter, which finds use in the ply industry shows an MAI (Mean Annual Increment) of $\sim 0.25 \mathrm{~m}$ per year.

Our principal objective in this study was to investigate the variations in growth responses to elevated $\mathrm{CO}_{2}$ in tropical tree species of the same family. A second objective was to investigate responses of gas exchange parameters and biochemicals to elevated temperature and $\mathrm{CO}_{2}$ in the two tropical tree seedlings neem and melia. We aimed to test the hypothesis: growth responds more strongly to elevate $\mathrm{CO}_{2}$ in the slow growing neem than in the fast growing Melia seedlings grown in unfertilized soil.

\section{MATERIALS AND METHODS}

Seedlings of Melia dubia Cav. and Azadirachta indica A. Juss were subjected to germination. Uniform seedlings of the experimental species approximately $10 \mathrm{~cm}$ tall were selected and transplanted into bags $(30 \times 25 \mathrm{~cm})$. The initial biomass was measured on seedlings of the same size. The pots were filled with equal proportions of river sand, farmyard manure and soil $(2: 1: 1)$. All plants were watered each morning to saturation.

All plants were grown in four chambers, of dimensions 3 x $3 \times 3 \mathrm{~m}$, fabricated with galvanized iron (GI) pipe frames and covered with polyvinyl chloride (PVC) sheet of $120 \mu$ gauge to have more than $90 \%$ transmittance of light with top open to maintain near-natural conditions. A software facility called Supervisory Control and Data Acquisition (SCADA) was used to continuously control, record and display the actual and desired $\mathrm{CO}_{2}$ level, relative humidity and temperature in each OTC by feedback control loop passing through Programmable Logical Controllers (PLC). The $\mathrm{CO}_{2}$ enrichment was done to maintain the level of concentrations (600 ppm and $900 \mathrm{ppm}$ ) using a $\mathrm{CO}_{2}$ cylinder, on a daily basis and the $\mathrm{CO}_{2}$ levels were monitored through SCADA and PLC. The experimental design used was randomized complete block design (RBD) with five replications. The treatments were:

- Treatment 1-Control chamber in order to study the effect of chamber environment $\left(\mathrm{CO}_{2}\right.$ concentration maintained same as the ambient i.e. $380 \mathrm{ppm})$.

- Treatment $2-600 \pm 50 \mathrm{ppm}$ level of $\mathrm{CO}_{2}$

- Treatment $3-900 \pm 50 \mathrm{ppm}$ level of $\mathrm{CO}_{2}$

- Treatment 4 - 900 ppm level of $\mathrm{CO}_{2}$ maintaining a temperature of ambient $+4^{\circ} \mathrm{C}$ (using humidifier)

- Control - Ambient conditions (prevailing $\mathrm{CO}_{2}$ levels - 380 ppm) with no chambers

There were $4 \mathrm{CO}_{2}$ treatments, 2 plant species $5 * 5$ replicate plants $=200$ total. In three chambers, air temperature was maintained at $30 / 22^{\circ} \mathrm{C}$ (day/night) with a photoperiod of $16 \mathrm{~h}$; relative humidity was ca. $50 \%$ and photosynthetic photon flux density (PPFD) was ca. $400 \mathrm{mmol} \mathrm{m}{ }^{2} \mathrm{~s}^{1}$ during the day. The $\mathrm{CO}_{2}$ treatment lasted from 8th December to 12th April (125 days).

\subsection{Measurements of Leaf gas exchange}

Leaf gas exchange was measured with Li-6400 (Li-Cor, Lincoln, NE, USA). The net photosynthetic rate (Pn), transpiration rates $(\mathrm{E})$, stomatal conductance (gs) and internal carbon-di-oxide concentration $(\mathrm{Ci})$ were measured on fully expanded leaves to evaluate the effect of elevated $\mathrm{CO}_{2}$. All these measurements were recorded in twenty five plants per species and three replications per leaf 125 days after the seedlings were exposed to elevated $\mathrm{CO}_{2}$ concentrations. The measurements were performed at midday, between 1000 and 1200 eastern daytime, when the solar photosynthetic photon irradiance was saturated at 1000-1200 $\mu \mathrm{mol}$ $\mathrm{m}^{-2} \mathrm{~s}^{-1}$ under cloud free conditions. The photosynthetic chamber was calibrated at regular intervals using two reference $\mathrm{CO}_{2}$ cylinders before taking the measurements. After the reference $\mathrm{CO}_{2}$ concentration become stabilized ( $\sim \mathrm{min})$, the chamber $\mathrm{CO}_{2}$ was matched to the reference $\mathrm{CO}_{2}$ so that the chamber and reference $\mathrm{CO}_{2}$ concentrations were equilibrated prior to a leaf being inserted into the chamber. The leaf was allowed to equilibrate for $5 \mathrm{~min}$ before measurements were taken and the duration of each measurement was usually 30-45 seconds. To minimize the heat load within the cuvette, a small external fan was used to control temperature. The relative humidity at the inlet of the cuvette was kept between 60 and $80 \%$.

Water use efficiency (WUE) was calculated using net photosynthetic rate and transpiration $(\mathrm{Pn} / \mathrm{E})$. Intrinsic water use efficiency (IWUE) was calculated as the ratio of the net photosynthetic rate to the stomatal conductance (Pn/gs). Intrinsic carboxylation efficiency (ICE) was derived as the ratio of the net photosynthetic rate of intercellular $\mathrm{CO}_{2}$ concentration $(\mathrm{Pn} / \mathrm{Ci})$. Intrinsic Mesophyll Efficiency (IME) was derived as the ratio of intercellular $\mathrm{CO}_{2}$ concentration to the stomatal conductance (Ci/gs).

The long-term response of gs was quantified as the ratio of gs for plants grown at the elevated $\mathrm{CO}_{2}$ to those of plants grown at the ambient $\mathrm{CO}_{2}$, both variables measured at a standard $\mathrm{CO}_{2}$ concentration of $380 \mathrm{ppm}$. The direct or short- term effect (STE) of increasing $\mathrm{CO}_{2}$ concentration was quantified as the ratio of stomatal conductance ( $\mathrm{gs}$ ) measured at elevated $\mathrm{CO}_{2}$ concentration to the plant grown at the ambient growth conditions [15]. A similar ratio was calculated for the net $\mathrm{CO}_{2}$ assimilation rate (NAR), which was modified [16].

\subsection{Growth and Biochemical Measurements}

All plants were harvested and sorted into leaves, stems and roots at the end of the growth period. Roots, leaves, and stems were separated and dry weights were determined after $48 \mathrm{~h}$ in an oven set at $70{ }^{\circ} \mathrm{C}$. From the basic data on fresh weight and dry weight of root, shoot and leaves, derived parameters such as RootShoot allometric ratio (RSR) and percent of total biomass (TB) allocated to various plant organs ( LBP- Leaf Biomass Portioning; SBP- Shoot Biomass Portioning; RBP- Root Biomass Portioning) was calculated. Leaves were collected from the two tree species from each ambient and elevated OTCs. All samples were collected from fully expanded leaves at 8:00 h. The samples were 
immediately stored in $-20{ }^{\circ} \mathrm{C}$, and kept until analysis. Estimation of chlorophyll [17], protein [18], carbohydrate [19], reducing sugars [20], free amino acids [21], phenols [22], flavanoids [23]; DPPH scavenging assay [24], carbonic anhydrase [25] were carried out as described.

\subsection{Data analysis}

Effects of $\mathrm{CO}_{2}$ concentration, species, and their interaction on variables measured in this study were evaluated using analysis of variance (ANOVA) with SPSS statistics package. The comparison of means was conducted using the Duncan's Multiple Range Test (DMRT) where ANOVA showed a significant effect. Students' T test was performed to compare the effects of $\mathrm{CO}_{2}$ on performance of seedlings. Simple correlations were carried out with parameters which showed significant variations at interaction and treatment levels. Prior to statistical analyses, variables were checked for normality and transformed when necessary [26].

\section{RESULTS}

\subsection{Measurements of Leaf gas exchange}

Table 1a presents the significance levels for photosynthetic and gas exchange characteristics both at species and treatment levels and their interactions. Treatment levels and their interactions were found to be insignificant for all derived parameters namely WUE, IWUE, ICE and IME. At the species level, they varied significantly with respect to the different parameters assessed except $\mathrm{Ci}$ and IWUE. Various elevated $\mathrm{CO}_{2}$ treatments affected gas exchange characteristics but did not affect Pn. Interactive effects were significant only for transpiration and stomatal conductance.

Figure 1 presents the percent increase/decrease in response of the two species with respect to control subjected to different treatments. Gas exchange characteristics in neem increased in response to different treatments. In melia, Pn and gs showed an increase while $\mathrm{Ci}$ and $\mathrm{E}$ recorded a decrease. The increase in $\mathrm{Pn}$, gs and $\mathrm{E}$ of neem was very high ( $>75$ per cent) when compared to the corresponding increase in melia $(<25$ per cent) which was almost near normal values.

Among the derived physiological parameters, neem and melia showed increased response to all except IME. Contrarily, neem showed decreased response in the case of ICE. Overall, the response of melia was near normal in comparison to neem which showed wide variability.

Stomatal conductance showed an increase under short and long term exposure of neem with about 192 percent increase for short term and a reduction from the same in the long term (130 percent). A similar trend was observed towards photosynthetic responses also with Pn values showing an increase by 120 and 63 percent under short term and long term responses respectively (Table 2). Melia recorded low values with respect to short-term responses of stomatal conductance and photosynthetic responses (both non-significant at 5 per cent levels). However, the long-term responses increased for both parameters recording values of 11 and 21 per cent respectively which were significantly higher (Table 2).

Table 1a: Significance level (F value) of effects of different factors and factor interactions on physiological traits based on two-way ANOVA.

\begin{tabular}{|c|c|c|c|}
\hline Variables & Species & Treatments & Species x Treatment \\
\hline Net Photosynthetic Rate (Pn) & $29.766^{* *}$ & $0.657 \mathrm{~ns}$ & $0.771 \mathrm{~ns}$ \\
\hline Stomatal Conductance (gs) & $155.907 * *$ & $9.284 * *$ & $8.974 * *$ \\
\hline Intercellular $\mathrm{CO} 2$ Concentration $(\mathrm{Ci})$ & $3.828 \mathrm{~ns}$ & $1.41 * *$ & $1.674 \mathrm{~ns}$ \\
\hline Transpiration Rate $(\mathrm{E})$ & $254.931 * *$ & $6.22 * *$ & $6.393 * *$ \\
\hline Intrinsic Water Use Efficiency (WUE) & $5.487 * *$ & $0.613 \mathrm{~ns}$ & $1.616 \mathrm{~ns}$ \\
\hline Instantaneous Water Use Efficiency (IWUE) & $1.283 \mathrm{~ns}$ & $1.298 \mathrm{~ns}$ & $2.515 \mathrm{~ns}$ \\
\hline Intrinsic Carboxylation Efficiency (ICE) & $7.42^{* *}$ & $0.263 \mathrm{~ns}$ & $0.246 \mathrm{~ns}$ \\
\hline Intrinsic Mesophyll Efficiency (IME) & $24.522 * *$ & $0.175 \mathrm{~ns}$ & $0.231 \mathrm{~ns}$ \\
\hline
\end{tabular}

Significance levels: $\mathrm{ns}, \mathrm{p}>0.05 ;{ }^{*} \mathrm{p}<0.05 ; * * \mathrm{p}<0.01$

Table 1b: Significance level (F value) of effects of different factors and factor interactions on morphological traits based on two-way ANOVA.

\begin{tabular}{|c|c|c|c|}
\hline Variables & Species & Treatments & Species x Treatment \\
\hline Shoot length & $20.089 * *$ & $24.739 * *$ & $1.562 \mathrm{~ns}$ \\
\hline Number of Leaves & $28.85 * *$ & $0.601 \mathrm{~ns}$ & $0.219 \mathrm{~ns}$ \\
\hline Number of Roots & $27.692 * *$ & $1.681 \mathrm{~ns}$ & $0.519 \mathrm{~ns}$ \\
\hline Root length & $10.067 * *$ & $0.28 \mathrm{~ns}$ & $0.781 \mathrm{~ns}$ \\
\hline Root Shoot Ratio & $3.723 \mathrm{~ns}$ & $2.876 \mathrm{~ns}$ & $0.851 \mathrm{~ns}$ \\
\hline Total Biomass & $1.071 \mathrm{~ns}$ & $7.294 * *$ & $0.333 \mathrm{~ns}$ \\
\hline Root Biomass Partitioning & $7.205 * *$ & $2.727 \mathrm{~ns}$ & $1.969 \mathrm{~ns}$ \\
\hline Shoot Biomass Partitioning & $15.27 * *$ & $3.603 * *$ & $0.953 \mathrm{~ns}$ \\
\hline Leaf Biomass Partitioning & $4.046 \mathrm{~ns}$ & $3.619 * *$ & $1.531 \mathrm{~ns}$ \\
\hline
\end{tabular}

Significance levels: $n s, \mathrm{p}>0.05 ;{ }^{*} \mathrm{p}<0.05 ; * * \mathrm{p}<0.01$ 
Table 1c: Significance level (F value) of effects of different factors and factor interactions on biochemical traits based on two-way ANOVA.

\begin{tabular}{|c|c|c|c|}
\hline Variables & Species & Treatments & Species x Treatment \\
\hline Free amino acids & $10196.2^{* * *}$ & $654.5 * *$ & $544.8 * *$ \\
\hline Total Carbohydrates & $3097.8 * *$ & $44.8 * *$ & $55.1^{* *}$ \\
\hline Chlorophyll a & $81.5^{* *}$ & $11.1 * *$ & $33.7 * *$ \\
\hline Chlorophyll b & $6.5 * *$ & $30.9 * *$ & $18.6 * *$ \\
\hline Total Chlorophyll & $24.2 * *$ & $17.1 * *$ & $11.6 * *$ \\
\hline Total Proteins & $515.4 * *$ & $651.7 * *$ & $482.7 * *$ \\
\hline Free Reducing Sugars & $537.3 * *$ & $64.7 * *$ & $697.1 * *$ \\
\hline DPPH antioxidant assay & $6991.9 * *$ & $317.2 * *$ & $23.7 * *$ \\
\hline Flavonoids & $7088.1 * *$ & $466.3 * *$ & $629.4 * *$ \\
\hline Total phenolics & $420.1 * *$ & $71.9 * *$ & $68.0 * *$ \\
\hline Tannins & $270.7 * *$ & $144.7 * *$ & $48.2 * *$ \\
\hline Carbonic Anhydrase activity & $7991.6 * *$ & $747.6 * *$ & $987.6 * *$ \\
\hline
\end{tabular}

Significance levels: $\mathrm{ns}, \mathrm{p}>0.05 ;{ }^{*} \mathrm{p}<0.05 ; * * \mathrm{p}<0.01$

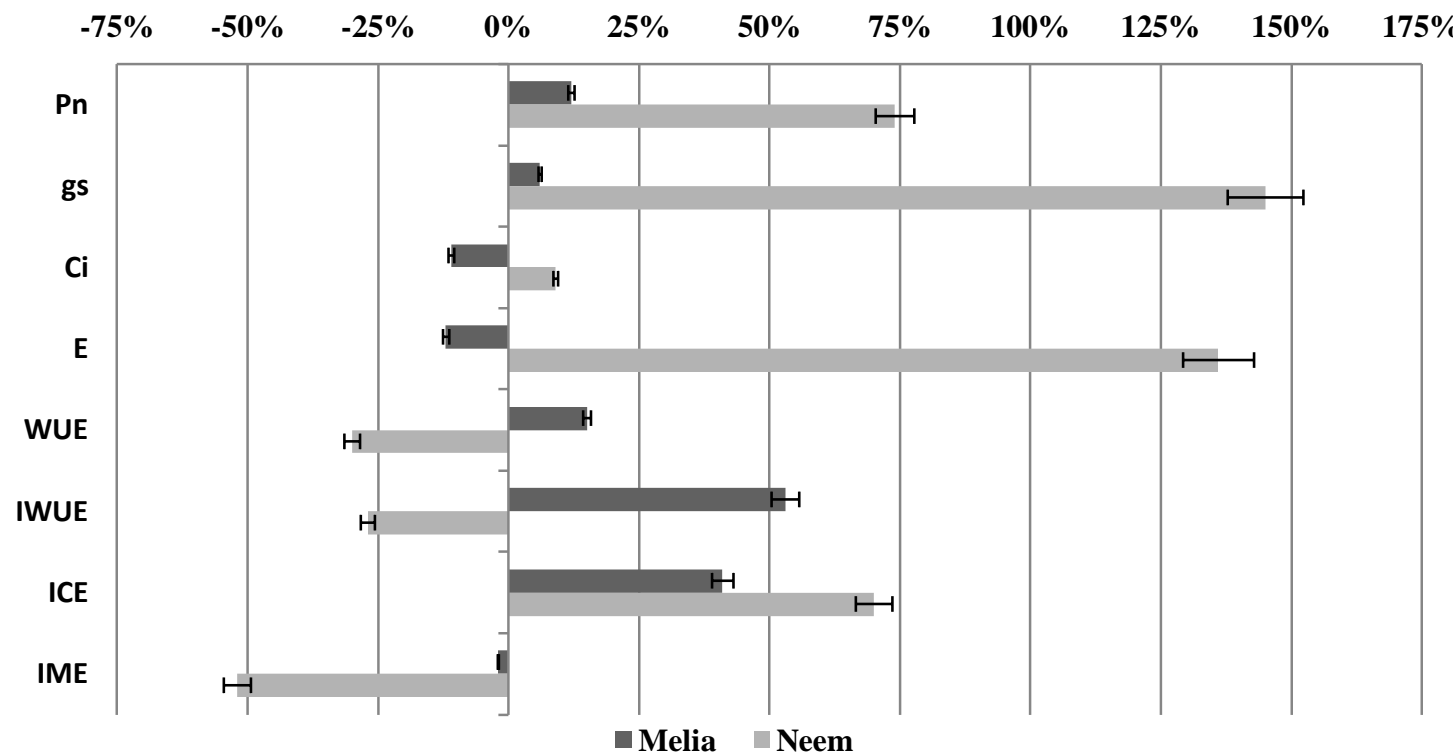

Fig. 1: The average increase (\%) in physiological parameters under chamber, elevated (600 ppm, $900 \mathrm{ppm}$ and $900 \mathrm{ppm}$ with RH) relative to ambient (380 ppm) $\mathrm{CO}_{2}$ for melia (dark shaded bars) and neem (light shaded bars). Net Photosynthetic Rate (Pn), Stomatal Conductance (gs), Intercellular CO2 Concentration (Ci), Transpiration Rate (E), Intrinsic Water Use Efficiency (WUE), Instantaneous Water Use Efficiency (IWUE), Intrinsic Carboxylation Efficiency (ICE), Intrinsic Mesophyll Efficiency (IME).

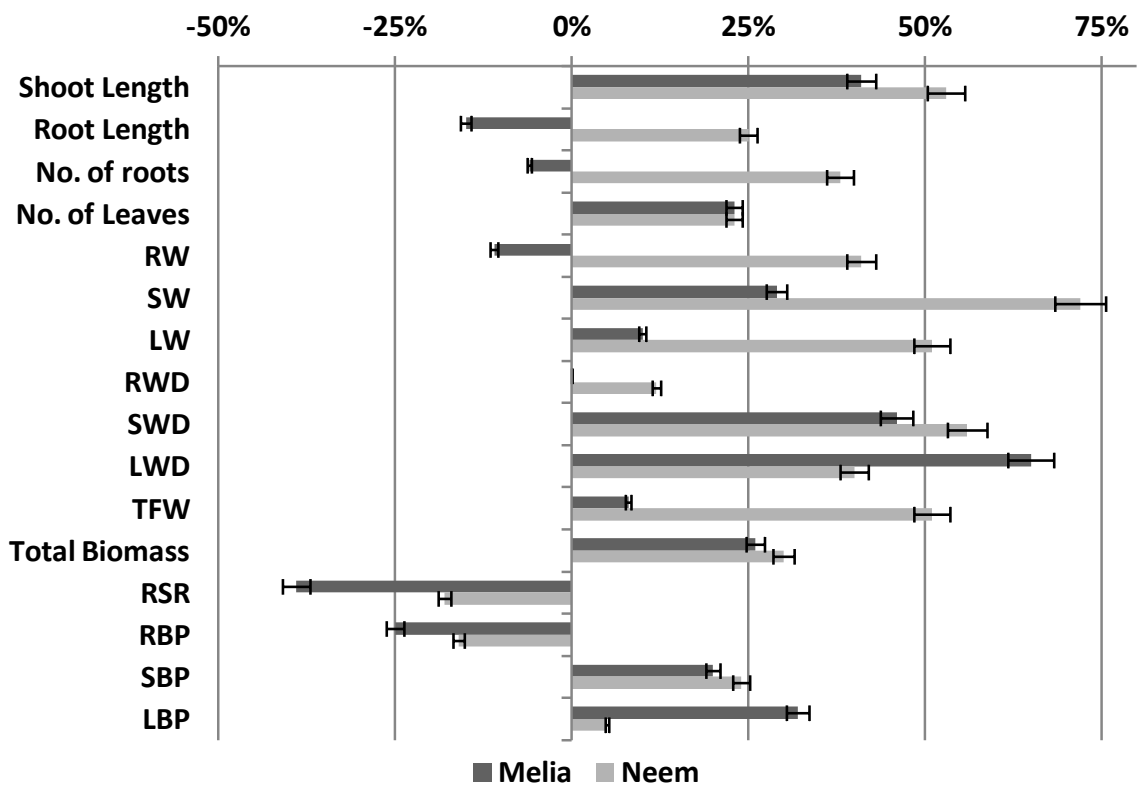

Fig. 2: The average increase $(\%)$ in growth under chamber, elevated $(600 \mathrm{ppm}, 900 \mathrm{ppm}$ and $900 \mathrm{ppm}$ with $\mathrm{RH}) \mathrm{relative}$ to ambient $(380 \mathrm{ppm}) \mathrm{CO}$ for melia (dark shaded bars) and neem (light shaded bars). RW -Root Weight (Fresh); SW - Shoot Weight(Fresh); LW - Leaf Weight(Fresh); RWD -Root Weight (Dry); SWD- Shoot Weight(Dry); LWD - Leaf Weight(Dry); TFW- Total Fresh Weight; RSR - Root/Shoot Ratio; RBP - Root Biomass Partitioning ;SBP - Shoot Biomass Partitioning; LBP - Leaf Biomass Partitioning. 


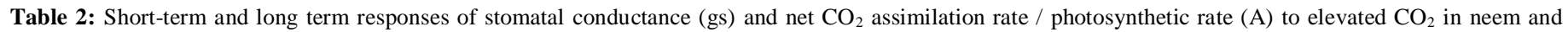
Melia seedlings.

\begin{tabular}{|c|c|c|c|c|}
\hline \multirow{2}{*}{ Species } & \multicolumn{2}{|c|}{ Stomatal response } & \multicolumn{2}{|c|}{ Photosynthetic response (NAR) } \\
\hline & Short-term & Long-term & Short-term & Long-term \\
\hline Neem & $2.92 *$ & $2.30 *$ & $2.20 *$ & $1.63^{*}$ \\
\hline Melia & 1.02 & $1.11^{*}$ & 0.93 & $1.21 *$ \\
\hline
\end{tabular}

* indicates a ratio significantly different from 1.0 , at $\mathrm{P}=0.05$.

Table 3: Simple Correlation between the overall biometric, physiological and biochemical parameters of neem and melia.

\begin{tabular}{|c|c|c|c|c|c|c|c|c|c|c|c|c|c|c|c|c|c|}
\hline & $\mathbf{A A}$ & CHO & PTN & RS & DPPH & FLA & PHE & $\mathbf{C A}$ & SL & $\mathbf{R L}$ & RSR & TB & Pn & gs & $\mathrm{Ci}$ & $\mathbf{E}$ & A:B \\
\hline$\overline{\mathrm{AA}}$ & 1 & & & & & & & & & & & & & & & & \\
\hline $\mathrm{CHO}$ & $.666^{* *}$ & 1 & & & & & & & & & & & & & & & \\
\hline PTN & 0.284 & 0.407 & 1 & & & & & & & & & & & & & & \\
\hline RS & -0.036 & -0.297 & 0.216 & 1 & & & & & & & & & & & & & \\
\hline DPPH & $-.747 * *$ & $-.882 * *$ & -0.092 & 0.384 & 1 & & & & & & & & & & & & \\
\hline FLA & $-.601 * *$ & $-.691 * *$ & -0.146 & $.572 * *$ & $.667 * *$ & 1 & & & & & & & & & & & \\
\hline PHE & $-.508 *$ & $-.552 *$ & 0.281 & $.475^{*}$ & $.628 * *$ & $.804 * *$ & 1 & & & & & & & & & & \\
\hline $\mathrm{CA}$ & $.543^{*}$ & $.694 * *$ & 0.39 & -0.391 & $-.532 *$ & $-.545^{*}$ & -0.41 & 1 & & & & & & & & & \\
\hline SL & -0.057 & -0.414 & $-.642 * *$ & $.480 *$ & 0.172 & 0.33 & -0.1 & $-.520^{*}$ & 1 & & & & & & & & \\
\hline RL & -0.408 & $-.574 * *$ & -0.04 & $.530 *$ & $.567 * *$ & $.583 * *$ & $.517 *$ & $-.610 * *$ & 0.441 & 1 & & & & & & & \\
\hline RSR & -0.365 & -0.281 & $.491 *$ & 0.172 & $.468^{*}$ & 0.33 & $.607 * *$ & -0.203 & -0.337 & $.690 * *$ & 1 & & & & & & \\
\hline TB & -0.224 & 0.013 & -0.193 & 0.162 & -0.009 & 0.33 & -0.027 & -0.043 & 0.352 & 0.278 & -0.01 & 1 & & & & & \\
\hline $\mathrm{Pn}$ & $-.619 * *$ & $-.761 * *$ & -0.319 & $.492 *$ & $.724 * *$ & $.598 * *$ & 0.376 & $-.697 * *$ & $.536^{*}$ & $.563 * *$ & 0.166 & 0.316 & 1 & & & & \\
\hline gs & $-.525 *$ & $-.746^{* *}$ & -0.326 & $.666^{* * *}$ & $.703 * *$ & $.603^{* *} *$ & 0.368 & $-.721 * *$ & $.654 * *$ & $.590 * *$ & 0.09 & 0.226 & $.873^{* *}$ & 1 & & & \\
\hline $\mathrm{Ci}$ & $.488^{*}$ & 0.312 & 0.307 & 0.153 & -0.175 & -0.225 & -0.151 & 0.296 & -0.118 & -0.119 & -0.004 & -0.25 & $-.469^{*}$ & -0.292 & 1 & & \\
\hline $\mathrm{E}$ & $-.618 * *$ & $-.822 * *$ & -0.303 & $.661 * *$ & $.789 * *$ & $.768^{* * *}$ & $.547^{*}$ & $-.740 * *$ & $.611 * *$ & $.660 * *$ & 0.198 & 0.285 & $.881^{* *}$ & $.959 * *$ & -0.261 & 1 & \\
\hline$A: B$ & 0.03 & 0.133 & 0.018 & 0.052 & -0.217 & 0.289 & 0.186 & -0.322 & 0.053 & 0.256 & 0.185 & 0.35 & -0.11 & -0.163 & 0.119 & -0.028 & 1 \\
\hline
\end{tabular}

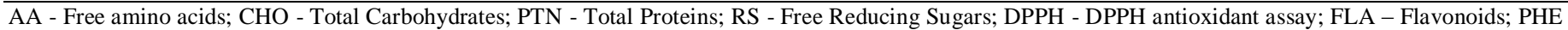

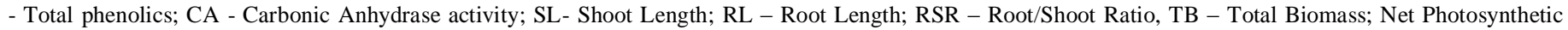
Rate (Pn), Stomatal Conductance (gs), Intercellular CO2 Concentration (Ci), Transpiration Rate (E), A:B - Chlorophyll a:b ratio.

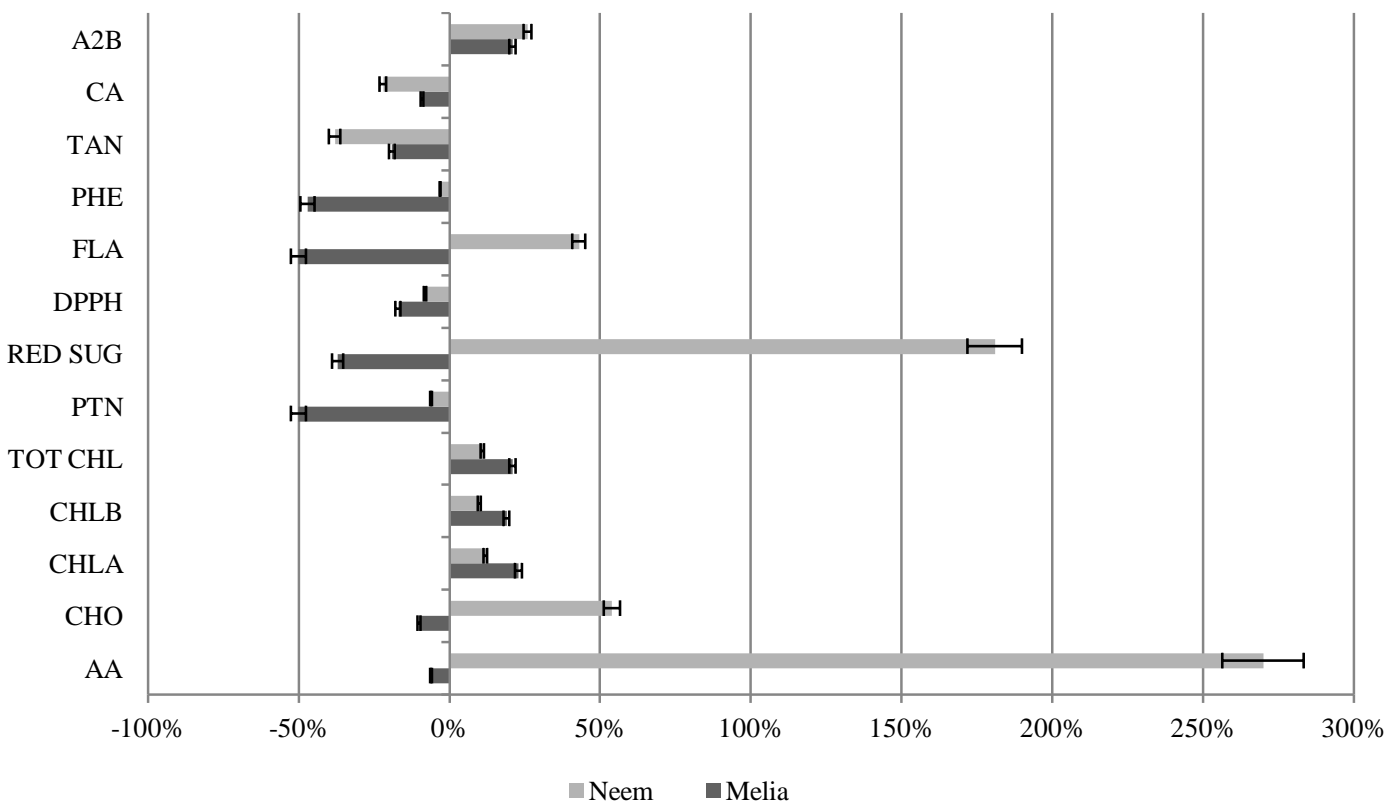

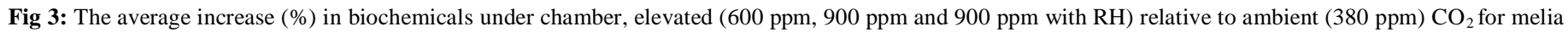

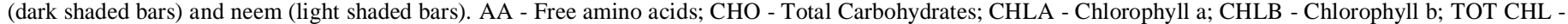

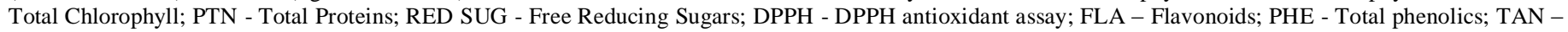
Tannins; CA - Carbonic Anhydrase activity; A2B - Chlorophyll a:b ratio. 


\subsection{Growth and Biochemical Measurements}

Species level variations were significant for most parameters except RSR, LBP, and total biomass. Treatment effects showed significant differences for shoot length, total biomass, and partitioning in stem and leaves. Interaction effects of species and treatments were non-significant with respect to morphological/ biometric traits (Table $1 \mathrm{~b}$ ).

Figure 2 presents the overall response of the two species to different treatments. All the parameters recorded higher values than control in neem. Except root dry weight, RSR, and RBP all other parameters recorded $>20$ percent increase. Though RSR and RBD recorded a decrease with respect to control, it was less than 20 percent. In melia, all root related parameters showed a decrease in response to treatments. It varied from 0 to 40 percent (Fig. 2).

All biochemical parameters showed significant variations with respect to species, treatments and interaction effects at 1 per cent level (Table 1c). From Figure 3, it is very evident that treatments had a positive effect on the chlorophylls of both species including total and a:b ratio. CA, along with secondary metabolites, antioxidant activity, and proteins recorded a decrease with respect to the control in both species. However, with respect to amino acids, carbohydrates, flavanoids and reducing sugars, neem displayed an increase while in melia, it was lower than the control.

\subsection{Correlation Studies}

Simple correlations presented in Table 3 discuss the correlations between the biometric, physiological and biochemical parameters. Root length showed significant positive correlation $(\mathrm{P}>0.01)$ with $\mathrm{Pn}, \mathrm{gs}, \mathrm{E}$, reducing sugars, flavanoids, phenols, DPPH activity, and was negatively correlated with total carbohydrates. Similarly, shoot length showed significant positive correlation $(\mathrm{P}>0.01)$ with $\mathrm{Pn}$, gs, E, reducing sugars, and was negatively correlated with proteins and CA activity. Total biomass was not correlated with any of the parameters selected. Root Shoot Ratio showed significant positive correlation with proteins, DPPH activity, and phenols.

\section{DISCUSSION}

Elevated $\mathrm{CO}_{2}$ stimulated changes in morphology and biomass allocation differently depending on species. Comparing the two species of Meliaceae, it was found that elevated $\mathrm{CO}_{2}$ induced significant changes in plant morphology which includes the plant height, leaves and consequently increased shoot weight along with significantly enhanced biomass allocation toward stems and leaves. The increase in the percent of the total biomass in these two plants grown in the elevated $\mathrm{CO}_{2}$ treatment (Fig 2) was consistent with a previous report of Quercus cerrioides and $Q$. ilex (27). It is postulated that elevated $\mathrm{CO}_{2}$ atmosphere might show a preferential allocation to roots, thus increasing their root/shoot ratio [28]. However, in the present study, both species showed lower ratios than the ambient indicating a relatively higher allocation of biomass to the shoots than the roots. The results suggest that both species had higher morphological plasticity for adjusting their biomass allocation to acclimatize to a new environment. Another feature observed was that between the two species, melia showed a preferential increase in shoot characteristics following treatments while the response of root related parameters was decreased. This could be attributed to the fast growing nature of the species.

Photosynthetic activity is a primary physiological process of biomass production. Any alteration in the photosynthesis process could lead to a change in total biomass accumulation. At elevated $\mathrm{CO}_{2}$ concentrations, the average stimulation of total biomass in both species was high, which was in accordance with the observed photosynthesis stimulation.

Short-term experiments in tree species exposed to elevated $\mathrm{CO}_{2}$ levels have shown increased photosynthetic rate up to $40-80 \%$ in pine seedlings (29). A $110 \%$ increased annual total net photosynthesis in elevated $\mathrm{CO}_{2}$ than in an ambient $\mathrm{CO}_{2}$ level [30]. Short-term exposure of $\mathrm{C} 3$ plants to elevated $\mathrm{CO}_{2}$ concentrations generally stimulates plant photosynthesis (31) and a proportional increase in biomass as a result of the improved competitiveness of $\mathrm{CO}_{2}$ over $\mathrm{O}_{2}$ as a substrate for the enzyme ribulose-1,5-bisphosphate carboxylase/oxygenase (32). Compared to Melia, greater stimulation of photosynthesis by elevated $\mathrm{CO}_{2}$ was observed in neem suggesting that this species might possess enhanced physiological regulation mechanisms at elevated $\mathrm{CO}_{2}$ (Table 2). Increased stomatal conductance and photosynthetic responses under short and long term exposure of neem are indicative of the fact that neem has the ability to adapt to elevated $\mathrm{CO}_{2}$ levels. Melia showed stability during short-term exposures while the long-term exposure observations warrants further and elaborate studies in the species with respect to gas exchange studies over longer periods of time to understand the acclimation mechanism in the species.

In general, photosynthetic activity is controlled by abilities of light energy transformation and utilization, $\mathrm{CO}_{2}$ carboxylation in photosynthetic apparatus as well as stomatal conductance. There exists a clear difference in gas exchange between the two species under elevated $\mathrm{CO}_{2}$ concentrations (Fig 1 ), which resulted in the different photosynthesis responses.

Experiments conducted in open-top chambers (OTCs) environment showed significant increases in light-saturated rates of photosynthesis in several $\mathrm{C}_{3}$ plants grown at elevated $\mathrm{CO}_{2}(33)$. Further, $\mathrm{Ci} / \mathrm{gs}$ is a reflection of mesophyll efficiency, and this shows the significant inverse relationship with assimilation rate, Pn (34). The marked increase in net assimilation rates has been explained to be due to increased intercellular $\mathrm{CO}_{2}$ concentrations (Ci) (35). Increase in stomatal conductance has been reported in a cultivar of Avena sativa [41] and the stomatal effect has been reported to depend on water supply in Eucalyptus cladocalyx [36]. In Eucalyptus 30 percent reduction in transpiration at $680 \mathrm{ppm}$ of $\mathrm{CO}_{2}$ and at saturating light intensity, compared to ambient conditions has been reported [37]. 
Plants respond to the changes in the environment not only by altering their physiological processes but also adjust biochemically. Studies on $\mathrm{CO}_{2}$ enrichment report changes in biochemical composition, carbonic anhydrase, and nitrate reductase activity, and that the response is species specific [38]. Elevated $\mathrm{CO}_{2}$ concentration of $600 \mathrm{ppm}$ was favourable for enhancement of total chlorophylls in A. indica and M. dubia. This is contrary to reports that chlorophylls and stomatal conductance decreased in plants grown under elevated $\mathrm{CO}_{2}$ compared to ambient $\mathrm{CO}_{2}$ level [39]. Further, the accumulation of carbohydrates is reported to have a feedback inhibitory effect on photosynthetic rate, thereby reducing the chlorophyll content both $a$ and $b$ in this species [40]. However, this was not observed. The photosynthetic machinery was not severely affected due to high concentrations of $\mathrm{CO}_{2}$ in both species, as is evident from Fig 3 which also favours the chlorophyll enhancement. Chlorophyll $\mathrm{a} / \mathrm{b}$ ratio was observed to increase in both species following treatments. Variation in response of chlorophyll content to $\mathrm{eCO}_{2}$ and elevated temperature has been reported in cultivars of Avena sativa some showing increase while others showing no response [41].

Foliar carbohydrates accumulate in the leaves of $\mathrm{C} 3$ plants grown at elevated $\mathrm{CO}_{2}$ concentration and has been reported as one of the most pronounced and universal changes observed. Neem accumulated more carbohydrates and reducing sugars at elevated $\mathrm{CO}_{2}$ concentrations. This is in accordance with reports [4, 42] that stimulation of carbon assimilation rates resulting from internal $\mathrm{CO}_{2}$ concentrations in the leaves of plants in an enriched environment leads to increased stem and foliar biomass and higher levels of carbohydrates. Free reducing sugars and carbohydrates reduced in melia under the treatments, though they are generally reported to increase under $\mathrm{eCO}_{2}$ [42 -46]. However, the notable increase in carbohydrate concentration could be due to nonreducing sugars which ultimately build up non-structural carbohydrates.

Neem and melia recorded a decline in the total protein concentration. This is in accordance with previous studies carried out under elevated $\mathrm{CO}_{2}$ [47-50]. Plants lose the ability to take up soil nitrate (most common form of nitrogen) and convert it into organic compounds such as proteins at enriched $\mathrm{CO}_{2}$ conditions. According to this hypothesis, it was reported that increasing carbon dioxide levels in the atmosphere could reduce crops' protein content by $20 \%$ [51]. Thus, elevated $\mathrm{CO}_{2}$ has always found to have negative effects on foliar protein content. The free amino acid content of neem was found to increase with elevated $\mathrm{CO}_{2}$. An adaptation response to elevated $\mathrm{CO}_{2}$ stress was observed. This was in accordance with reports that the ratio of free minor amino acids at elevated $\mathrm{CO}_{2}$ to that at current $\mathrm{CO}_{2}$ was significantly greater [52]. On the contrary, melia recorded a significant decrease in total free amino acid contents when the high concentration of $\mathrm{CO}_{2}$ was supplied. This may be due to the lack of sufficient nutrient intake particularly nitrogen assimilation [51].

Most amino acids get converted to their derivatives by free radicals. These free radicals were those that are produced from phenols and polyphenols which when present in excess get converted from antioxidants to pro-oxidants [53]. Both species showed a notable decrease in phenolic and tannin contents. The decrease in phenolic content and carbohydrate accumulation reveals that carbon partitioning is favoured for carbohydrate accumulation rather than phenolic biosynthesis, especially in melia under elevated $\mathrm{CO}_{2}$ levels. This was in accordance with the reports on other species [54]. It was previously reported that there was no significant difference in the antioxidant activity at elevated $\mathrm{CO}_{2}$ [55] or enhanced flavonoid and antioxidant property [56]. Contrarily, the results of present study showed a notable decrease in the non-enzymatic antioxidant activity on $\mathrm{CO}_{2}$ enrichment. Both the species recorded a uniform decline in antioxidant activity. It is suggested that there is no direct correlation between high levels of starch accumulation and photosynthetic acclimation, and it is possible that increased starch levels, rather than feeding back to reduce photosynthetic capacity, enable the plants to avoid the down-regulation of photosynthesis, by preventing cycling and/or accumulation of soluble sugars [57]. A strong positive correlation between Pn and gs, with a large increase in Pn with a relatively small decrease in gs has been reported also in Avena sativa [41]. The increase of phenols under $\mathrm{eCO}_{2}$ is consistent with the general response of plants found positively correlated with photosynthetic rates, increase in soluble sugars and total non-structural carbohydrates [58-59]. In the present study, shoot and root length showed significant positive correlation $(\mathrm{P}>0.01)$ with $\mathrm{Pn}$, gs, E and reducing sugars similar to the reports available. Root to shoot ratio was also significantly correlated with phenols.

In general, plants acclimate and adapt to the prevailing environmental conditions to optimize their growth and survival. Initially, when the atmospheric $\mathrm{CO}_{2}$ concentration is increasing, the first effect is on the photosynthetic enzymes. All the other adjustments originate from this primary effect. The present study which attempted to understand effects of elevated $\mathrm{CO}_{2}$ on two species of Meliaceae family revealed that growth responses, gas exchange parameters, and biochemicals varied significantly and was species specific. Growth response was better in the slow growing neem than in the fast growing Melia.

\section{CONCLUSION}

The study emphasizes the need to assess all important tropical tree species individually and not to generalize the response of tree species to elevated $\mathrm{CO}_{2}$. Studies report the positive response of these three plantation species, namely teak, casuarinas and Ailanthus to increased $\mathrm{CO}_{2}$ concentrations [60]. In addition, multiple environmental factors must be considered and their interactive effect on predicted climate change is needed to be studied and understood. The immediate and significant increase in photosynthesis can be exploited as a major strategic adaptation to mitigate the global rise in atmospheric $\mathrm{CO}_{2}$. The study is indicative that neem adapts better than melia under changing environmental conditions, having higher short-term and long term responses, suggesting its relative success in the field under a future elevated $\mathrm{CO}_{2}$ regime. 


\section{ACKNOWLEDGEMENT}

The authors are grateful to the State Planning Commission, Govt. of Tamil Nadu, India for financial support.

\section{REFERENCES}

1. Zhang L, Wu D, Shi H, Zhang C, Zhan X, et al. Effects of Elevated $\mathrm{CO}_{2}$ and $\mathrm{N}$ Addition on Growth and $\mathrm{N}_{2}$ Fixation of a Legume Subshrub (Caragana microphyllaLam.) in Temperate Grassland in China. PLoS ONE. 2011; 6(10): e26842.

2. Razzaque, M.A., M.M. Haque, Q.A. Khaliq, A.R.M. Soliman, A. Hamid. Effects of $\mathrm{CO}_{2}$ and nitrogen levels on yield and yield attributes of rice cultivars. Bangl. J. Agric. Res. 2011; 36(2): 213221.

3. Sharafzadeh, S. and K. Ordookhani. Organic and biofertilizers as a good substitute for inorganic fertilizers in medicinal plants framing. Australian Journal of Basic and Applied Science. 2011; 5(2):13301333.

4. Curtis P.S., Drake B.G., Leadly P.W., Arp W.J. and Whigham D.F. Growth and senescence in plant communities exposed to elevated $\mathrm{CO}_{2}$ concentrations on an estuarine marsh. Oecologia. 1989; 78, 20 26.

5. Oberbour, S. F., Strain, B.R. and Fetcher, N. Effect of $\mathrm{CO}_{2}$ enrichment on seedling physiology and growth of two tropical tree species. Physiol. Plant. 1985; 65: 342-356.

6. Norby, R. J. Nodulation and nitrogenase activity in nitrogen-fixing woody plants stimulated by $\mathrm{CO}_{2}$ enrichment of the atmosphere. Physiologia Plantarum. 1987; 71:77-82.

7. O'Neill, B. F., Zangerl, A. R., Delucia, E., And Berenbaum, M. R. Longevity and fecundity of Japanese beetle (Popillia japonica) on foliage grown under elevated carbon dioxide. Environ. Entomol. 2008; 37: 601-607

8. Ainsworth E.A. and Long S.P. What have we learned from 15 years of free-air $\mathrm{CO} 2$ enrichment (FACE)? A meta-analytic review of the responses of photosynthesis, canopy. New Phytol., 2005; 165, 351371

9. Huang J.G., Bergeron Y., Denneler B., Berninger F. and Tardif J. Response of forest trees to increased atmospheric $\mathrm{CO} 2$. Critical Reviews in Plant Sciences. 2007; 26, 265-283.

10. Saxe H., Ellsworth D.S. and Heath J. Tree and forest functioning in an enriched CO2 atmosphere. New Phytol. 1998; 139: 395-436.

11. Curtis P.S. and Wang X.Z. A meta-analysis of elevated CO2 effects on woody plant mass, form, and physiology. Oecologia, 1998; 113, 299-313.

12. Roberntz P. Atmospheric carbon dioxide concentration, nitrogen availability, temperature and the photosynthetic capacity of currentyear Norway spruce shoots. Tree Physiol. 2001. 21(12-13):931-40.

13. Wang K.Y., Kellomaki S. and Laitinen K. Effects of needle age, long term temperature and $\mathrm{CO} 2$ treatments on the photosynthesis of scots pine. Tree Physiology. 1995; 15: 211-218.

14. Tjoelker M.G., Oleksyn J. and Reich P.B. Seedlings of five boreal tree species differ in acclimation of net photosynthesis to elevated CO2 and temperature. Tree Physiology. 1998; 18: 715-726.

15. Del Pozo, A., Perez, P., Morcuende, R., Alonso, A., MartinezCarrasco, R. Acclimatory responses of stomatal conductance and photosynthesis to elevated $\mathrm{CO} 2$ and temperature in wheat crops grown at varying levels of $\mathrm{N}$ supply in a Mediterranean environment. Plant Sci. 2005; 169, 908-916.

16. Zhang, Y., Duan, B., Qiao, Y., Wang, K., Korpelainen, H. and Li, C. Leaf photosynthesis of Betula albosinensis seedlings as affected by elevated $\mathrm{CO} 2$ and planting density. Forest Ecology and Management. 2008; 255: 1937-1944.

17. Arnon D.I. Copper enzymes in isolated chloroplasts. Polyphenoloxidase in Beta vulgaris. Plant Physiol., 1949; 24, 1-15.

18. Lowry O.H., Rosebrough N.J, Farr A.L, Randall R.J. Protein measurement with the Folin- phenol reagent. Journal of Biological Chemistry. 1951; 193: 265-275.
19. Hedge J.E. and Hofreiter B.T. Carbohydrate Chemistry, 17 (Eds Whistler R.L. and Be Miller, J.N.), Academic Press, New York.1962.

20. Miller G.L. Use of Dinitrosalicylic Acid Reagent for Determination of. Reducing Sugar. Analytical Chemistry. 1972; 31:426-428.

21. Moore S. and Stein, W.H. Methods in Enzymol, (Eds. Colowick, S.P. and Kaplan, N.D.) Academic Press, New York. 1948; 468.

22. Malik C.P. and Singh M.B. Plant enzymology and Histo enzymology, Kalyani Publishers, New Delhi. 1980.

23. Lin JY, and Tang CY. Determination of total phenolic and flavonoid contents in selected fruits and vegetables, as well as their stimulatory effect on mouse splenocyte proliferation. Food Chem. 2007; 101:140-147.

24. Amal, A.I.M.; Mokhtar, M.M. and Rasha, M.F. Antitumor and antibacterial activities of [1-(2-ethyl, 6-heptyl) phenol] from Cuminum cyminum seeds. J. Appl. Sci. Res., 2009; 11: 1881-1888.

25. Warrier, RR, Lalitha S, Savitha C. A Modified Assay of Carbonic Anhydrase Activity in Tree Species. BBR-Biochemistry and Biotechnology Reports. 2014; 3(1): 48-55.

26. Gomez KA and Gomez AA. Statistical procedures for agricultural research. $4^{\text {th }}$ Edition. John Wiley and sons, Inc. London, UK. 1984. pp. 13-175.

27. Cortes P, Josep Maria Espelta, Robert Save and Carme Biel. Effects of a nursery $\mathrm{CO} 2$ enriched atmosphere on the germination and seedling morphology of two Mediterranean oaks with contrasting leaf habit. New Forests. 2004; 28: 79-88.

28. Tingey D.T., Phillips D.L. and Johnson M.G. Elevated CO2 and conifer roots: effects on growth, life span and turnover. New Phytol. 2000; 147: 87-103.

29. Green, K. and Wright, R. D. Field response of photosynthesis to CO2 enrichment in Ponderosa Pine. Ecology. 1977. 58: 687-692.

30. Wang, Y.P., Rey, A. and Jarvis, P.G. Carbon balance of young birch trees grown in ambient and elevated atmospheric $\mathrm{CO} 2$ concentrations. Global Change Biology. 1998; 4: 797-807.

31. Saralabai, V.C., Vivekanandan, M., Babu, R.S. Plant responses to high CO2 concentration in the atmosphere. Photosynthetica. 1997; 33:7-37.

32. Woodward, E.L., Thompson, G.B. and McKee, I.F. The effects of elevated concentrations of carbon dioxide on individual plants, populations, communities and ecosystems. Annals of Botany. 1991; 67: 23-28.

33. Mauney, J. R., Lewin, K. F., Hendrey, G. R. and Kimball, B. A., Growth and yield of cotton expose to free-air $\mathrm{CO} 2$ enrichment. Crit. Rev. Plant Sci., 1992; 11: 213-222.

34. Sheshshayee M.S., Krishna Prasad B.T., Natraj K.N., Shankar A.G., Prasad T.G., Uday Kumar M. Ratio of intercellular CO2 concentration to stomatal conductance is a reflection of mesophyll efficiency. Curr. Sci. 1996; 70:672-675.

35. Ogren, W. L. Affixing the O to RUBISCO: Discovering the source of photorespiratory glycolate and its regulation. Photosynth. Res. 2003; 76: 53-63.

36. Palanisamy, K. Interactions of elevated $\mathrm{CO} 2$ concentration and drought stress on photosynthesis in Eucalyptus cladocalyx F. Muell. Photosynthetica. 1999; 36: 635-638.

37. Ravichandran, V., Pathmanabhan, G. and Janaguiraman, M.D. Green House Gases Stress. In: Dwivedi, P. and Dwivedi, R.S. (Eds.) Physiology of abiotic stress in plants, Agrobios. 2005; Pp. 35-78.

38. Xia, J.-R. and Gao, K.-S. Impacts of Elevated $\mathrm{CO}_{2}$ Concentration on Biochemical Composition, Carbonic Anhydrase, and Nitrate Reductase Activity of Freshwater Green Algae. Journal of Integrative Plant Biology. 2005; 47: 668-675.

39. Girish Kumar Rasineni, Anirban Guha, Attipalli Ramachandra Reddy. Elevated atmospheric $\mathrm{CO}_{2}$ mitigated photoinhibition in a tropical tree species, Gmelina arborea. J.Photobiol. 2011. 2,24.

40. Strain B.R. and Thomas R.B. Anticipated effects of elevated $\mathrm{CO}_{2}$ and climate change on plants from Mediterranean-type ecosystems utilizing results of studies in other ecosystems. In: Global Change and Mediterranean-Type Ecosystems. Ecological Studies,Vol. 117 (eds J.M. Moreno and W. C. Oechel). 1995; 121-139. 
41. Bhatt, R.K. Baig, M.J. Tiwari, H.S. Elevated $\mathrm{CO}_{2}$ influences photosynthetic characteristics of Avena sativa $\mathrm{L} \quad$ cultivars. Journal of Environmental Biology. 2010; 31 (5): 813-818.

42. Shahidul Islam, Sharmin Khan and James O. Garner. Elevated Atmospheric $\mathrm{CO}_{2}$ Concentration Enhances Carbohydrate Metabolism in Developing Lycopersicon esculentum Mill. Cultivars. International Journal of Agriculture and Biology. 2006; 8(2): 157-161.

43. Griffin KL, Anderson OR, Gastrich MD, Lewis JD, Lin GH, Schuster W, Seemann JR, Tissue DT, Turnbull MH, Whitehead D.Plant growth in elevated $\mathrm{CO}_{2}$ alters mitochondrial number and chloroplast fine structure. Proceedings of the National Academy of Sciences, USA. 2001; 98:2473-2478.

44. Wiemken, V. and Ineichen, K. Seasonal fluctuations of the levels of soluble carbohydrates in spruce needles exposed to elevated $\mathrm{CO} 2$ and nitrogen fertilization and glucose as a potential mediator of acclimation to elevated CO2. Journal of Plant Physiology. 2000; 156: 746-750.

45. Rays Williams., Richard J. Norby and David E. Lincoln. Effects of elevated $\mathrm{CO}_{2}$ and temperature-grown red and sugar maple on gypsy moth performance. Global Change Biology. 2000; 6: 685-695.

46. Rolland F, Moore B, Sheen J. Sugar sensing and signaling in plants. Plant Cell (suppl.).: 2002; 14: S185-S205

47. Wilkins D., Van Oosten J.J., Besford R.T. Effects of elevated $\mathrm{CO}_{2}$ on growth and chloroplast proteins in Prunus avium. Tree Physiol. 1994; $14,767-779$.

48. Lianhong Gu, Paul J. Hanson, W. Mac Post, Dale P. Kaiser, Bai Yang, Ramakrishna Nemani, Stephen G. Pallardy, and Tilden Meyers. The 2007 Eastern US Spring Freeze: Increased Cold Damage in a Warming World. BioScience. 2008; 58(3), 253-262.

49. Gordillo, F.J.L., Niell, F.X. and Figueroa, F.L. Non-photosynthetic enhancement of growth by high $\mathrm{CO} 2$ level in the nitrophilic seaweed Ulva rigida C. Agardh (Chlorophyta). Planta. 2001. 213: 64-70.

50. Ingvar Simonsson, Bengt-Harald Jonsson and Sven Lindskog. Phenol, a competitive inhibitor of $\mathrm{CO}_{2}$ hydration catalyzed by carbonic anhydrase. Biochem Biophys Res Commun. 1982; 108(4):1406-1412.

51. Lucina $\mathrm{M}, \mathrm{F}$. Rising $\mathrm{CO}_{2}$ levels could reduce protein in crops. Science. 2010; 328:899-903.

52. Rogers, A., Allen, D. J., Davey, P. A., Morgan, P. B., Ainsworth, E. A., Bernacchi, C. J., Cornic, G., Dermody, O., Dohleman, F. G., Heaton, E. A., Mahoney, J., Zhu, X.-G., Delucia, E. H., Ort, D. R. and Long, S. P. Leaf photosynthesis and carbohydrate dynamics of soybeans grown throughout their life-cycle under Free-Air Carbon dioxide Enrichment. Plant, Cell \& Environment. 2004; 27: 449-458.

53. Azam S, Hadi N, Khan N.U, Hadi S.M. Prooxidant property of green tea polyphenols epicatechin and epigallocatechin-3-gallate: implications for anticancer properties. Toxicol In Vitro. 2004; 18(5): 55-61.
54. Lindroth R.L. Impacts of Elevated Atmospheric $\mathrm{CO}_{2}$ and $\mathrm{O}_{3}$ on Forests: Phytochemistry, Trophic Interactions, and Ecosystem Dynamics. J Chem Ecol. 2010; 36:2-21.

55. Goncalves, B., Falco, V., Moutinho-Pereira, J., Bacelar, E., Peixoto, F. and Correia, C. Effects of elevated $\mathrm{CO}_{2}$ on grapevine (Vitis vinifera L.): Volatile composition, phenolic content, and in vitro antioxidant activity of red wine. Journal of Agricultural and Food Chemistry. 2009. 57: 265-273.

56. Bridget F. O'Neill, Arthur R. Zangerl, Orla Dermody, Damla D. Bilgin, Clare L. Casteel, Jorge A. Zavala, Evan H. DeLucia, May R. Berenbaum. Impact of Elevated Levels of Atmospheric $\mathrm{CO}_{2}$ and Herbivory on Flavonoids of Soybean (Glycine max Linnaeus). Journal of Chemical Ecology. 2010; 36(1):35-45.

57. Davey PA, Olcer H, Zakhleniuk O, Bernacchi CJ, Calfapietra C, Long SP, Raines CA. Can fast-growing plantation trees escape biochemical down-regulation of photosynthesis when grown throughout their complete production cycle in the open air under elevated carbon dioxide? Plant, Cell and Environment. 2006 29:1235-1244

58. Ghasemzadeh A, Jaafar HZE, Rahmat A. Antioxidant activities, total phenolics and flavonoids content in two varieties of Malaysia young ginger (Zingiber officinale Roscoe). 2010. Molecules, 15(6): 43244333.

59. Ghasemzadeh, A. and Jaafar, H.Z.E. Effect of $\mathrm{CO}_{2}$ Enrichment on Some Primary and Secondary Metabolites synthesis in Ginger (Zingiber officinale Roscoe). International Journal of Molecular Science. 2011. 12(2): 1101-1114.

60. Warrier, R.R., Buvaneswaran, C., Priyadharshini, P. and Jayaraj, R.S.C. Growth response of three plantation species of the tropics exposed to elevated $\mathrm{CO}_{2}$ levels. Journal of Forestry Research. 2013; 24: 449-456.

\section{How to cite this article:}

Janani S., Priyadharshini P., Jayaraj RSC, Buvaneswaran C. Warrier RR. Growth, physiological and biochemical responses of Meliaceae species-Azadirachta indica and Melia dubia to elevated $\mathrm{CO}_{2}$ concentrations. J App Biol Biotech. 2016; 4 (03): 052-060. DOI: 10.7324/JABB.2016.40309 